tion in The A.O.U. Check-list of North American Birds (1957). Correspondence with zoos and avaries in western Canada indicate that it has not been kept in captivity here. However, it is apparently kept in some zoos in the western United States. The duck in question may have escaped captivity and migrated north, possibly mated to a Blue-winged Teal. I favour that explanation for its presence in Alberta, rather than the possibility that it represents an erratic wanderer from its indigenous range.

\title{
Banded Ross' Goose Recovered in Regina
}

\author{
by Douglas E. Wade and Dorothy R. Wade, Regina
}

On December 5, 1962, Mrs. Wade saw a white goose on the open water of the Regina Waterfowl Park. On December 6, in company with Margaret Belcher and Robert Nero, we were unable to get a close enough view of this goose to determine whether it was a Snow Goose or a Ross' Goose. On December 9, we were able to see it at close range through $12 \mathrm{X}$ binocoulars and saw there was no "grinning patch." On December 15, we were able again to get close to the bird and could see a metal band on its right leg and confirm the absence of a "grinning patch." The goose was seen subsequently by us on December 19 and 30 . On all of these dates the bird appeared to be in excellent flying condition and was often seen in flights with Canada Geese and Mallards. It would land and take off with no apparent difficulty. It was an active feeder and was seen going through preening activities. It was also seen by George and Marjorie Ledingham, Vic Wilshire, Allan Smith and Alan Wade-the last three on the Christmas Count day (December 30). Fred Lahrman, of the Saskatchewan Museum of Natural History, had been able to see the goose and had determined it to be a Ross' Goose.

On January 5 and 6 we and two other groups were unable to spot the zoose. Later, we learned that the 'Ross' Goose had been found dead on January 6 in one of the open-water channels across from the city power house by Ricky Sanderson. He turned the bird over to the Museum of Natural History to be prepared as a specimen. The Museum reported its weight as 2 lbs. 91/2 oz. Ralph Carson of the Museum also reported that the carcass showed evidence of several hotgun pellets having recently pene- trated the body. Presumably the bird had been shot at (illegally) when going to feed in grain stubble beyond the city limits. There was no evidence of lead shot in the gizzard, although some wheat grain remnants and quartz sand-size granules were found. The goose was a female.

Knowing that a number of Ross' geese had been banded in Saskatchewan, we got in touch with Mr. Alex Dzubin, wildlife biologist with the Canadian Wildlife Service in Saskatoon. In his letter of January 7 he wrote:

“The Ross' Goose No. 667-65331 which you observed in Regina and which was subsequently recovered has the following history. It was an adult female banded on September 30,1962 , at Buffalo Coulee, which is situated four miles north and four miles west of Colville, Saskatchewan, at $51^{\circ} 46^{\prime} \mathrm{N}$. and $109^{\circ} 18^{\prime} \mathrm{W}$. in the Kindersley District of west-central Saskatchewan. The bird was the last one banded of 141 Ross' caught by cannon net traps on that day. A crew made up of personnel of the Canadian Wildlife Service, Nebraska Game, Forestation and Parks Commission, U.S. Bureau of Sports Fisheries and Wildlife, and Colorado Game and Fish Department co-operated in the fall banding project at Kindersley.

"Total bandings of this species [in 1962 ] were 770 . Last year's total was 442. Most Ross' winter in the Sacramento Valley of California; the few recoveries of 1961 birds are from this wintering area. No recoveries l except the Regina bird] of 1962 banded birds are available as yet but I have a half dozen sight recoveries of red and yellow dyed Ross' from Montana and central California." 